NASA/TM-2010-216251/REV1

\title{
High-Pressure Angle Gears: Comparison to Typical Gear Designs
}

Robert F. Handschuh and Andrew J. Zakrajsek

Glenn Research Center, Cleveland, Ohio

This printing replaces NASA/TM-2010-216251, March 2010. 


\section{NASA STI Program . . . in Profile}

Since its founding, NASA has been dedicated to the advancement of aeronautics and space science. The NASA Scientific and Technical Information (STI) program plays a key part in helping NASA maintain this important role.

The NASA STI Program operates under the auspices of the Agency Chief Information Officer. It collects, organizes, provides for archiving, and disseminates NASA's STI. The NASA STI program provides access to the NASA Aeronautics and Space Database and its public interface, the NASA Technical Reports Server, thus providing one of the largest collections of aeronautical and space science STI in the world. Results are published in both non-NASA channels and by NASA in the NASA STI Report Series, which includes the following report types:

- TECHNICAL PUBLICATION. Reports of completed research or a major significant phase of research that present the results of NASA programs and include extensive data or theoretical analysis. Includes compilations of significant scientific and technical data and information deemed to be of continuing reference value. NASA counterpart of peer-reviewed formal professional papers but has less stringent limitations on manuscript length and extent of graphic presentations.

- TECHNICAL MEMORANDUM. Scientific and technical findings that are preliminary or of specialized interest, e.g., quick release reports, working papers, and bibliographies that contain minimal annotation. Does not contain extensive analysis.

- CONTRACTOR REPORT. Scientific and technical findings by NASA-sponsored contractors and grantees.
- CONFERENCE PUBLICATION. Collected papers from scientific and technical conferences, symposia, seminars, or other meetings sponsored or cosponsored by NASA.

- SPECIAL PUBLICATION. Scientific, technical, or historical information from NASA programs, projects, and missions, often concerned with subjects having substantial public interest.

- TECHNICAL TRANSLATION. Englishlanguage translations of foreign scientific and technical material pertinent to NASA's mission.

Specialized services also include creating custom thesauri, building customized databases, organizing and publishing research results.

For more information about the NASA STI program, see the following:

- Access the NASA STI program home page at http://www.sti.nasa.gov

- E-mail your question to help@sti.nasa.gov

- Fax your question to the NASA STI Information Desk at 443-757-5803

- Phone the NASA STI Information Desk at 443-757-5802

- Write to: STI Information Desk NASA Center for AeroSpace Information 7115 Standard Drive Hanover, MD 21076-1320 
NASA/TM-2010-216251/REV1

\section{High-Pressure Angle Gears: Comparison to Typical Gear Designs}

Robert F. Handschuh and Andrew J. Zakrajsek

Glenn Research Center, Cleveland, Ohio

National Aeronautics and

Space Administration

Glenn Research Center

Cleveland, Ohio 44135

June 2012 


\section{Document Change History}

NASA/TM-2010-216251/REV1, June 2012

\section{High-Pressure Angle Gears: Comparison to Typical Gear Designs \\ Robert F. Handschuh and Andrew J. Zakrajsek}

This printing replaces NASA/TM-2010-216251, March 2010; extensive changes were made to the document.

Level of Review: This material has been technically reviewed by technical management.

Available from

NASA Center for Aerospace Information 7115 Standard Drive

Hanover, MD 21076-1320
National Technical Information Service 5301 Shawnee Road Alexandria, VA 22312 


\title{
High-Pressure Angle Gears: Comparison to Typical Gear Designs
}

\author{
Robert F. Handschuh and Andrew J. Zakrajsek \\ National Aeronautics and Space Administration \\ Glenn Research Center \\ Cleveland, Ohio 44135
}

\begin{abstract}
A preliminary study has been completed to determine the feasibility of using high-pressure angle gears in aeronautic and space applications. Tests were conducted in the NASA GRC Spur Gear Test Facility at speeds up to $10,000 \mathrm{rpm}$ and $73 \mathrm{~N} * \mathrm{~m}$ (648 in.-1b) for 3.18, 2.12, and 1.59 module gears $(8,12$, and 16 diametral pitch gears), all designed to operate in the same test facility. The 3.18 module (8-diametral pitch), 28 tooth, 20 degree pressure angle gears are the NASA GRC baseline test specimen. Also, 2.12 module (12-diametral pitch), 42 tooth, 25 degree pressure angle gears were tested. Finally, 1.59 module (16-diametral pitch), 56 tooth, 35 degree pressure angle gears were tested. The high-pressure angle gears were the most efficient when operated in the high-speed aerospace mode $(10,000 \mathrm{rpm}$, lubricated with a synthetic turbine engine oil) and produced the lowest wear rates when tested with a perfluoroether-based grease. The grease tests were conducted at $150 \mathrm{rpm}$ and $71 \mathrm{~N}^{*} \mathrm{~m}(630 \mathrm{in} .-\mathrm{lb})$.
\end{abstract}

\section{Introduction}

Gearing is chosen very carefully for any given application to have a sufficient strength (load capacity) and, therefore, a long life before one of the many failure mechanisms initiates and results in component failure. Operating in very hostile environment conditions, such as large temperature swings, very abrasive dust, the use of nontraditional terrestrial lubricants, etc., premature failure can result (Refs. 1 and 2). In an attempt to improve gear performance, high-pressure angle (HPA) gearing is examined for possible use in space mechanism applications. As the pressure angle of a gear mesh increases, the rate of sliding of the surfaces over each other is reduced (Refs. 3 to 6). There are limits to how much the pressure angle can be increased as the design can eventually have a contact ratio approaching one and/or the tooth top land can become pointed. An approach to circumvent this dilemma is to make the gear mesh helical and use the face contact ratio to boost the overall contact ratio to a value greater than one (Refs. 7 and 8).

\section{Gear Design and Analysis}

To understand the effects of pressure angle increase, an analysis used for gear tooth contact fatigue was utilized. A computer code developed at NASA (Ref. 9) was used to calculate various parameters, including the sliding velocity of the teeth, and the resultant gear meshing power losses. The difference in sliding velocity between two of the designs tested is shown in Figure 1. The sliding velocity as a function of meshing position is shown for the $88.9 \mathrm{~mm}$ (3.5 in.) center distance (1:1 ratio) and two gear types - the standard 3.18 module ( 8 diametral pitch) 20 degree pressure angle and the high-pressure angle gears with 1.59 module (16 diametral pitch) and a 35 degree pressure angle.

There are other design considerations when changing to a higher-pressure angle. When trying to modify a design the pressure angle can only be modified so far for any given diametral pitch before tooth pointing can be design limiting. In the design mentioned in this report, the 35 degree pressure angle required doubling the diametral pitch. This increased the tooth count from 28 to 56 teeth. Also, due to the tooth pointing issues and the size of the teeth, the gear material, and the heat treatment process employed required modification. Instead of using 9310 gear steel and carburizing, Nitralloy $135 \mathrm{M}$ material using a nitriding heat treatment was chosen (very thin, hardened surface layer). With this material and heat-treat 


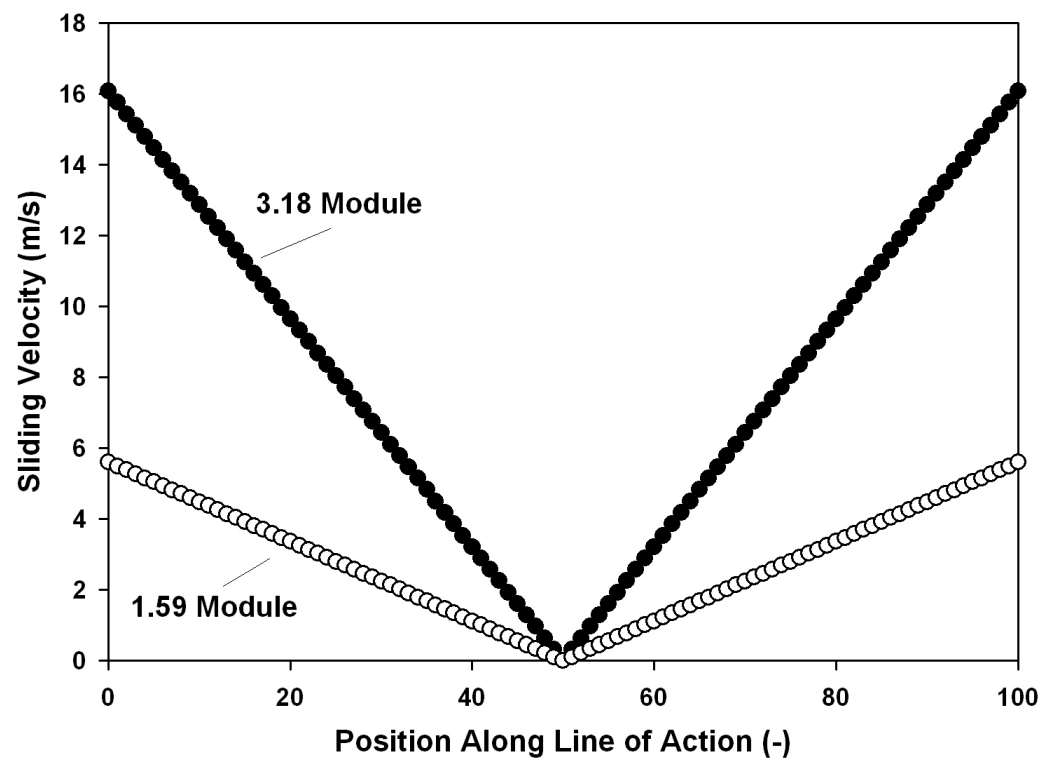

Figure 1.-Effect of gear design on sliding velocity at any point along the line of action between 3.18 and 1.59 module ( 8 and 16 diametral pitch) gears for a $1: 1$ ratio.

TABLE 1.- RESULTS FROM PERFORMANCE (EFFICIENCY) AND LOAD CAPACITY ANALYSIS CODES

\begin{tabular}{|l|c|c|c|}
\hline & $\begin{array}{c}\text { Standard gear } \\
\text { geometry \#1 }\end{array}$ & $\begin{array}{c}\text { Standard gear } \\
\text { geometry \#2 }\end{array}$ & $\begin{array}{c}\text { High pressure } \\
\text { angle }\end{array}$ \\
\hline Number of teeth & 28 & 42 & 56 \\
\hline Gear material & AISI 9310 & AISI 9310 & Nitralloy 135M \\
\hline Module, mm (diametral pitch, 1/in.) & $3.18(8)$ & $2.12(12)$ & $1.59(16)$ \\
\hline Pressure angle, degrees & 20 & 25 & 35 \\
\hline Addendum, mm (in.) & $3.18(0.125)$ & $2.12(0.083)$ & $1.40(.055)$ \\
\hline Outside diameter, mm (in.) & $95.25(3.75)$ & $93.17(3.668)$ & $91.69(3.610)$ \\
\hline Chordal tooth thickness, mm (in.) & $4.85(0.191)$ & $3.25(0.128)$ & $2.41(0.095)$ \\
\hline Clearance, mm (in.) & $0.79(0.031)$ & $0.79(0.031)$ & $0.19(0.0075)$ \\
\hline Face width, mm (in.) & $6.35(0.25)$ & $6.35(0.25)$ & $6.35(0.25)$ \\
\hline Center distance, mm (in.) & $88.9(3.5)$ & $88.9(3.5)$ & $88.9(3.5)$ \\
\hline Profile shift (-) & 0 & 0 & 0 \\
\hline Backlash, mm (in.) & $0.15(0.006)$ & $0.15(0.006)$ & $0.076(0.003)$ \\
\hline Contact ratio & 1.64 & 1.53 & 1.16 \\
\hline $\begin{array}{c}\text { Efficiency, load, and stress, at 10000 rpm, } \\
71 \text { N*m (630 in*lb) torque }\end{array}$ & & & 99.77 \\
\hline Efficiency, \% & 99.41 & 99.62 & $1601.4(360)$ \\
\hline Tangential load, N (lbs) & $1601.4(360)$ & $1601.4(360)$ & $1121.4(252.1)$ \\
\hline Radial load, N (lbs) & $582.7(131.0)$ & $746.9(167.9)$ & $0.308(44.6)$ \\
\hline Bending stress, GPa, (ksi) & $0.246(35.7)$ & $0.353(51.2)$ & $0.89(129.1)$ \\
\hline Contact stress, GPa (ksi) & $1.09(158.1)$ & $1.03(149.3)$ & \\
\hline Note: Beni) & & & \\
\hline
\end{tabular}

Note: Bending and contact stress found via ISO6336 (Ref. 10).

change the gears could be normally manufactured without the threat of tooth capping. Capping occurs when carburized surfaces come together at thin material regions, such as at the top of the tooth, and the induced stress field, from the heat-treating process, causes the material to fracture even without an applied load.

The designs and the results of analysis are shown in Table 1. Calculations were made for the gears operating at $10,000 \mathrm{rpm}$ using a synthetic aerospace lubricant. The one item to note in the table is that while the tangential load is the same (torque), the separating force between the gears has nearly doubled with the high-pressure angle design. While the design changes reduced the gearing losses, they increased the load the bearings must carry. 
ISO 6336 analysis was conducted on these three gear designs for tooth bending and contact stress. The results are shown in Table 1. From Table 1, the results between the three designs were fairly comparable with the 3.18 module ( 8 diametral pitch) gears having the lowest bending stress and the 1.59 module (16 diametral pitch) gears having the lowest contact stress.

\section{Experimental Results}

Test procedure: Testing was done in two different modes for the gears evaluated in this study. The basic properties of the two lubricants used are provided in Table 2. In the high-speed test mode, the gears were lubricated with a synthetic turbine engine lubricant. The gear mesh was lubricated with the jet pointing into mesh. The lubricant is gravity drained and returned to the lubricant reservoir. Lubricant temperature was measured just prior to the jet and at the exit region (drain) of the test gear cover. The load applied was measured statically using a torque wrench and was proportional to the torque actuator pressure applied. For these high-speed tests, the facility was brought up to full speed (10,000 rpm) prior to increasing the load to the maximum conditions tested.

In the low-speed, grease-lubricated mode, both the gears and the amount of grease applied were weighed prior to testing, and the gears were also weighed post test. Gears were rotated up to the $150 \mathrm{rpm}$ condition where tests were run prior to increasing to the maximum load applied (pressure on torque actuator).

\section{High-Speed Aerospace (Rotorcraft) Operation}

Three-gear designs were tested in the same gearbox, at identical rotational speed, torque, lubricant, and inlet temperature. A photograph of the three designs tested is shown in Figure 2. The test rig used in this study is shown schematically in Figure 3. In this test rig, the drive motor only needs to provide enough power to overcome the losses within the geared system. A rotating torque actuator uses fluid pressure to apply torque by rotating one of the slave gears (shown in green) relative to its shaft. The test gears are shown in red in the figure. Tests were conducted at full-face width contact for all tests.

TABLE 2.-BASIC PROPERTIES OF THE TWO LUBRICANTS USED IN THIS STUDY

\begin{tabular}{|l|c|c|}
\hline & Turbine engine lubricant & Space grease \\
\hline Mixture & Synthetic ester blend & Base oil-perfluorinated polyether \\
\hline Pour point, ${ }^{\circ} \mathrm{C}\left({ }^{\circ} \mathrm{F}\right)$ & $-62(-80)$ & $-73(-100)$ \\
\hline Specific gravity & 1 & 1.85 \\
\hline Viscosity, cSt. at $38^{\circ} \mathrm{C}, 100^{\circ} \mathrm{F}$ & 29.2 & 148 \\
\hline Viscosity, cSt. at $100^{\circ} \mathrm{C}, 210^{\circ} \mathrm{F}$ & 5.3 & 45 \\
\hline
\end{tabular}

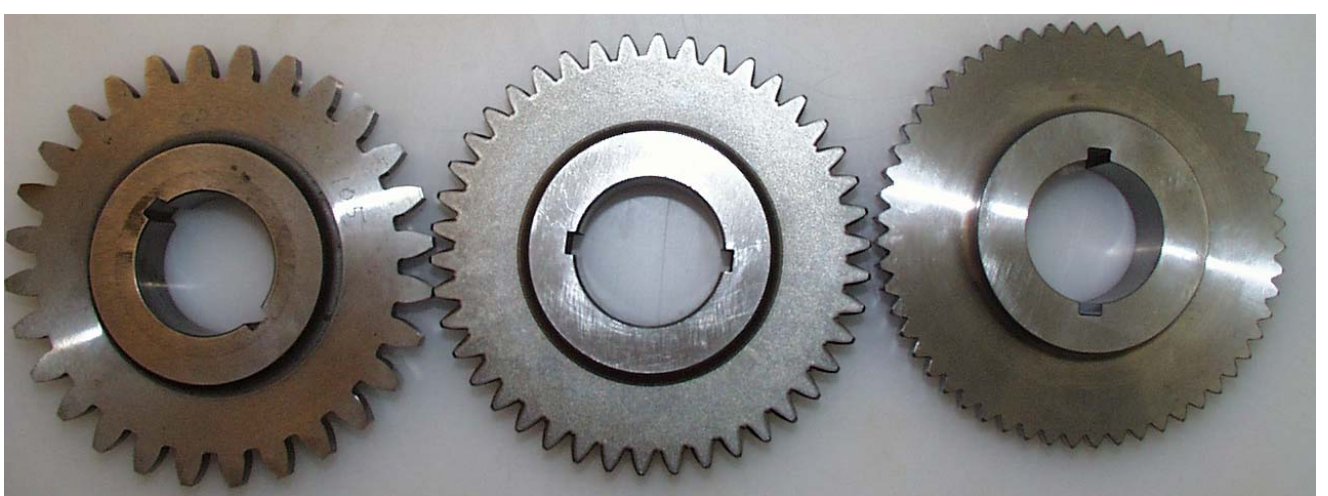

Figure 2.-Left to right: $3.18,2.12$, and 1.59 module $(8,12$, and 16 diametral pitch) test gears. 


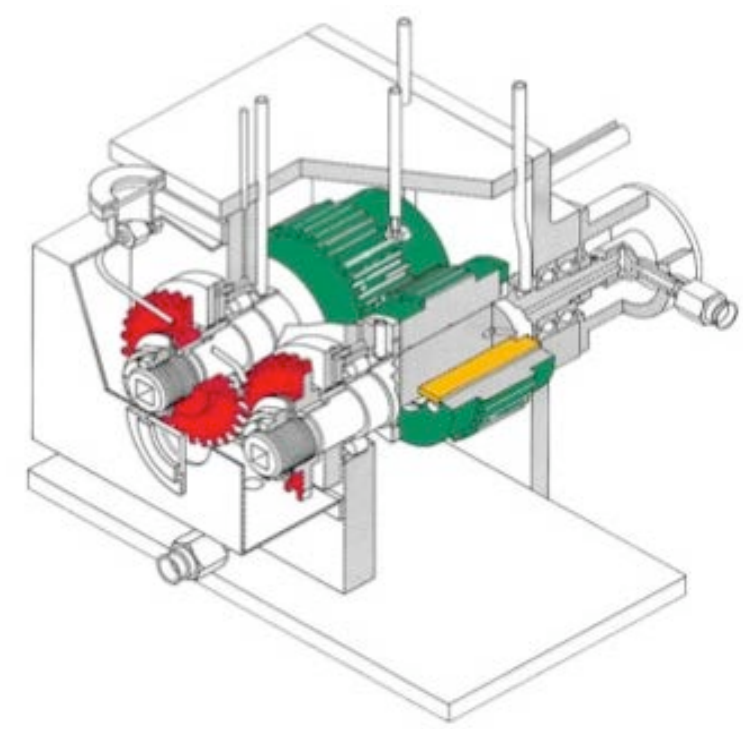

Figure 3.-Test facility at NASA Glenn Research Center.

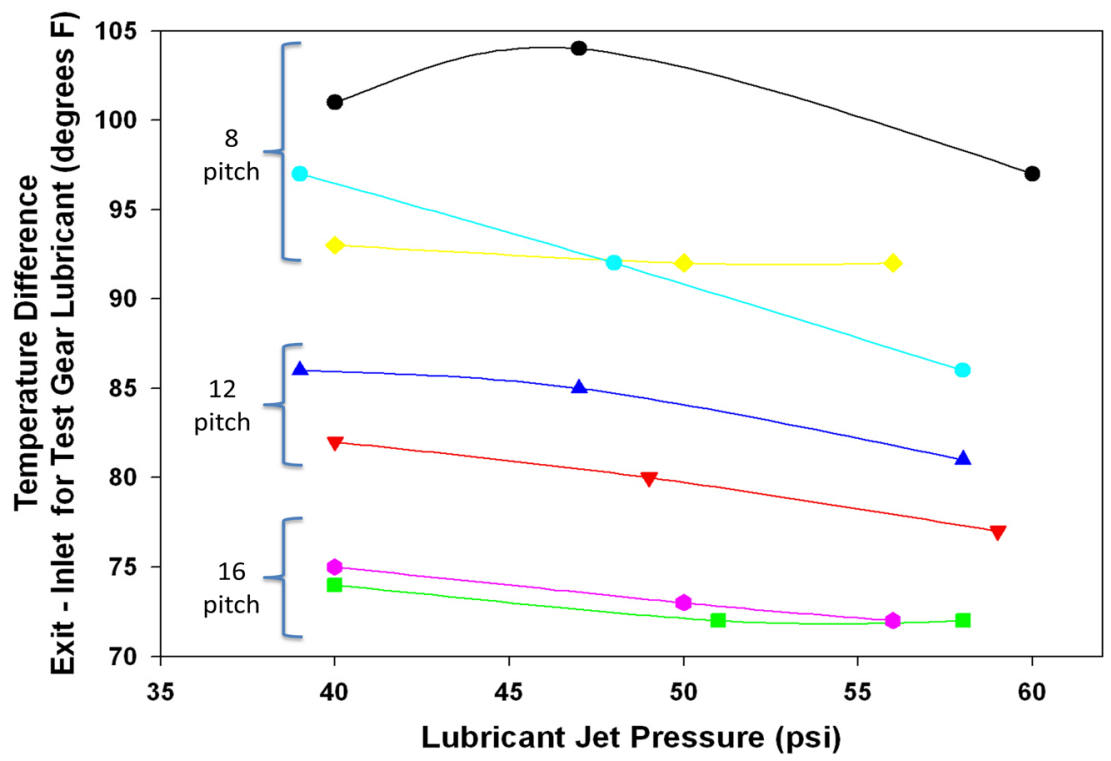

Figure 4.-Temperature results for three different gearing configurations. All tests conducted at $10,000 \mathrm{rpm}, 71 \mathrm{~N}^{*} \mathrm{~m}(630 \mathrm{in}$. $-\mathrm{lb})$. Flow rate at $40 \mathrm{psi} 8.1 \mathrm{ml} / \mathrm{s}(0.13 \mathrm{gpm})$.

The gears were tested at three levels of lubricant jet pressure (flow). The lubricant inlet and outlet temperatures were monitored throughout the tests. The data acquired for each gear design is shown in Figure 4. Seven different tests were conducted to generate the data shown in Figure 4. A comparison of the results indicates there is a definite difference between the three gear designs.

The lubricant temperature rise across a gearbox is a function of the gear meshing losses and any resultant windage losses. Pitch line velocity for these tests was $48.8 \mathrm{~m} / \mathrm{s}(9160 \mathrm{ft} / \mathrm{min})$. Finer pitch teeth with high-pressure angle showed an improvement resulting in a lower temperature change across the gearbox. Lubricant jet pressure (flow) into the gearbox had a lesser effect for each of the gear configurations, but there was a definite trend of lower temperature difference as the jet pressure was increased. It would be expected that heat removed from the gearbox should be related to $\dot{m} C_{p} \Delta T$ (lubricant flow rate, heat capacity of the lubricant, and the temperature difference between inlet and outlet for the lubricant) if other effects are neglected. 
The high-pressure angle gears were included in two extensive operational tests on the same pair of gears. The gears were run full-face width at the same conditions as the lubricant tests previously discussed. Each test was run continuously at 10,000 rpm, $73 \mathrm{~N} * \mathrm{~m}$ (648 in.-lb) torque, for 300 million cycles. The gears are shown in Figure 5 before testing and in Figure 6 after testing. The post-test gear surfaces appeared to be in excellent condition, as shown in Figure 6. The only anomaly that occurred was a chip at the flank edge shown in Figure 7. The chipped edge is thought to be due to installation interference that occurred between the two test gears.

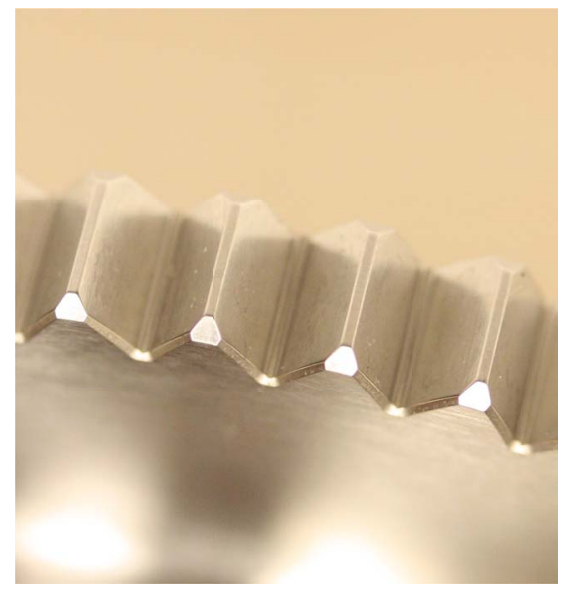

Figure 5.-Photograph of HPA gears before testing.

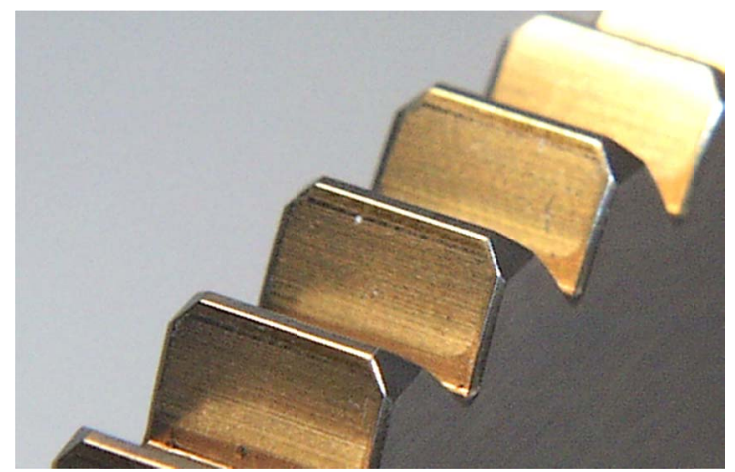

Figure 6.-Photograph of HPA gears after testing.

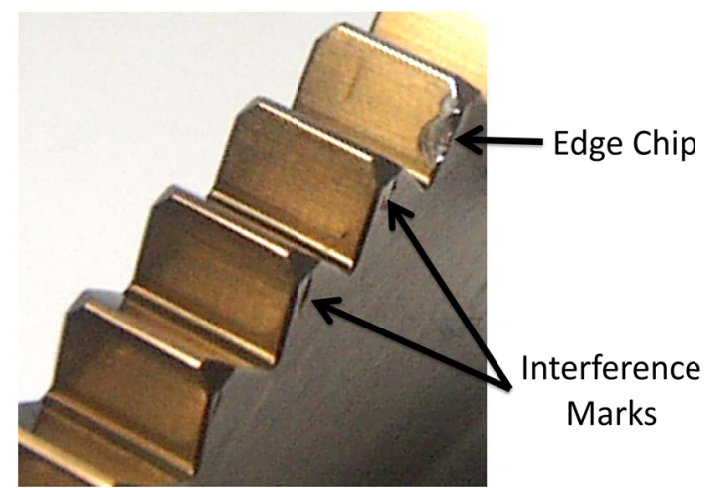

Figure 7.-Photograph of HPA gear flank end chip. 


\section{Perfluoroether (Space Qualified) Grease Tests}

The spur gears were lubricated with a grade 2, perfluoroether based grease commonly used in space (see Table 2). In space applications, perfluoroether-based grease is typically used because of its extremely low vapor pressure, to minimize out-gassing in a vacuum. Here, the wear study was conducted on the same test rig as previously described, except instead of spraying synthetic lubricant oil onto the meshing gears, they were lubricated with the space grease. The purpose of this part of the study was to investigate gear surface wear and to develop methods for keeping grease on the profile of the gear teeth.

The specifics of this test involve the previous three gear designs, 3.18, 2.12, and 1.59 module ( 8 pitch, 12 pitch, and 16 pitch) gears (refer to Fig. 2). The study consisted of 500,000 cycles for each set of gears with and without a grease retention shroud. The gears where rotated at $150 \mathrm{rpm}$ at a torque equal to $71 \mathrm{~N}^{*} \mathrm{~m}(630 \mathrm{in} .-\mathrm{lb})$. The grease was applied to the gears using a syringe before testing. The weight of the grease applied was measured before each test. Without the gear shrouds, significant wear was found in the 3.18 and 2.12 module ( 8 and 12 pitch) gears, with rust and black colored debris found in the gearbox housing cover (Fig. 8).

The 1.59 module (16 pitch) gears generated little debris, less than one half of the mass loss of the 2.12 module (12 pitch) gears and about one fourth of the mass loss of the 3.18 module ( 8 pitch) gears (Table 3). The teeth of the 3.18 and 2.12 module ( 8 and 12 pitch) gears indicated severe wear, primarily due to the meshing teeth squeezing out the perfluoroether-based grease allowing metal-to-metal contact.
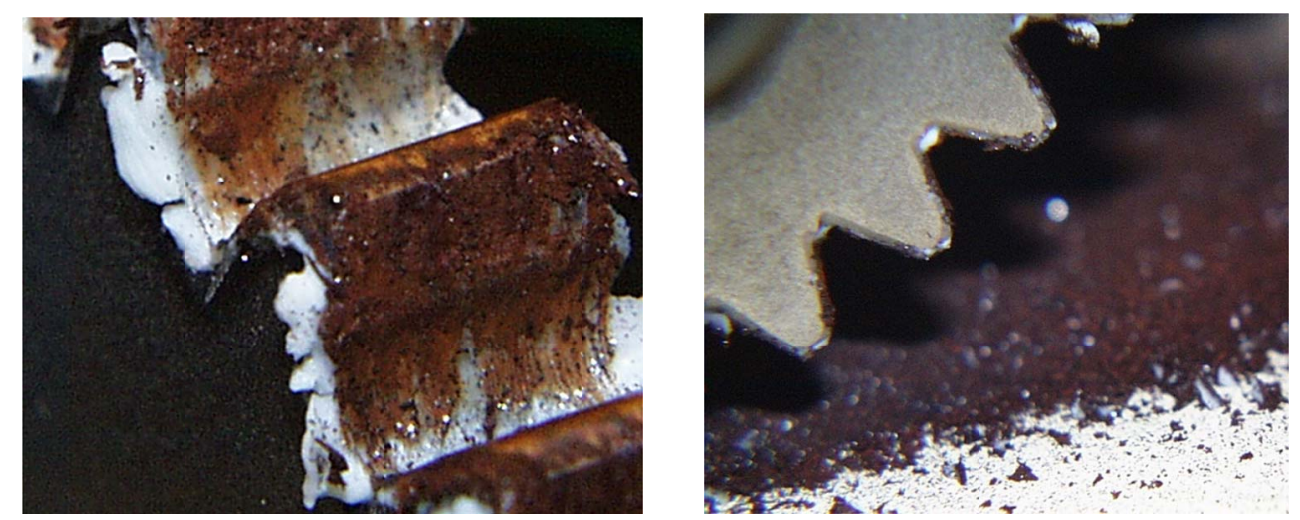

Figure 8.-Left: shows rust forming on the gear profile. Right: shows rust debris from metal on metal contact. (Both photos from a 2.12 module (12-diametral pitch) gear test.)

TABLE 3.--RESULTS FROM SPACE GREASE TESTING: $71 \mathrm{~N} * \mathrm{M}$ (630 IN.-LB) TORQUE AT 150 RPM

\begin{tabular}{|l|c|c|c|c|c|c|c|}
\hline $\begin{array}{c}\text { Module } \\
\text { (pitch) }\end{array}$ & Material & $\begin{array}{c}\text { Revolutions } \\
\text { or cycles }\end{array}$ & $\begin{array}{c}\text { Grease } \\
\text { applied } \\
(\mathrm{g})\end{array}$ & $\begin{array}{c}\text { Gear mass } \\
\text { loss } \\
(\mathrm{g})\end{array}$ & $\begin{array}{c}\text { Average initial } \\
\text { grease loss } \\
(\mathrm{g})\end{array}$ & $\begin{array}{c}\text { Shroud } \\
\text { Shroud grease } \\
\text { applied } \\
\text { (g) }\end{array}$ \\
\hline $3.18(8)$ & M50 & 400000 & 1.425 & 0.15 & ------- & No & 0 \\
\hline $3.18(8)$ & M50 & 400000 & 1.425 & 0.15 & ----- & No & 0 \\
\hline $3.18(8)$ & 9310 & 500000 & 1.19 & 0.95 & 0.305 & No & 0 \\
\hline $3.18(8)$ & 9310 & 500000 & 1.19 & 0.44 & 0.305 & No & 0 \\
\hline $2.12(12)$ & 9310 & 500000 & 1.02 & 0.57 & 0.04 & No & 0 \\
\hline $2.12(12)$ & 9310 & 500000 & 1.02 & 0.51 & 0.04 & No & 0 \\
\hline $1.59(16)$ & Nitralloy 135M & 500000 & 1.005 & 0.27 & 0.795 & No & 0 \\
\hline $1.59(16)$ & Nitralloy 135M & 500000 & 1.005 & 0.22 & 0.795 & No & 0 \\
\hline $1.59(16)$ & Nitralloy 135M & 500000 & 0.755 & 0 & 0 & Yes & \multirow{2}{*}{1.075} \\
\hline $1.59(16)$ & Nitralloy 135M & 500000 & 0.755 & 0 & 0 & Yes & Yes \\
\hline $2.12(12)$ & 9310 & 500000 & 1.285 & 0.25 & 0 & \multirow{2}{*}{2.215} \\
\hline $2.12(12)$ & 9310 & 500000 & 1.285 & 0.3 & 0 & Yes & \multirow{2}{*}{2.805} \\
\hline $3.18(8)$ & 9310 & 500000 & 0.66 & 0.46 & 0 & Yes & \\
\hline $3.18(8)$ & 9310 & 500000 & 0.66 & 0.37 & 0 & & \\
\hline
\end{tabular}




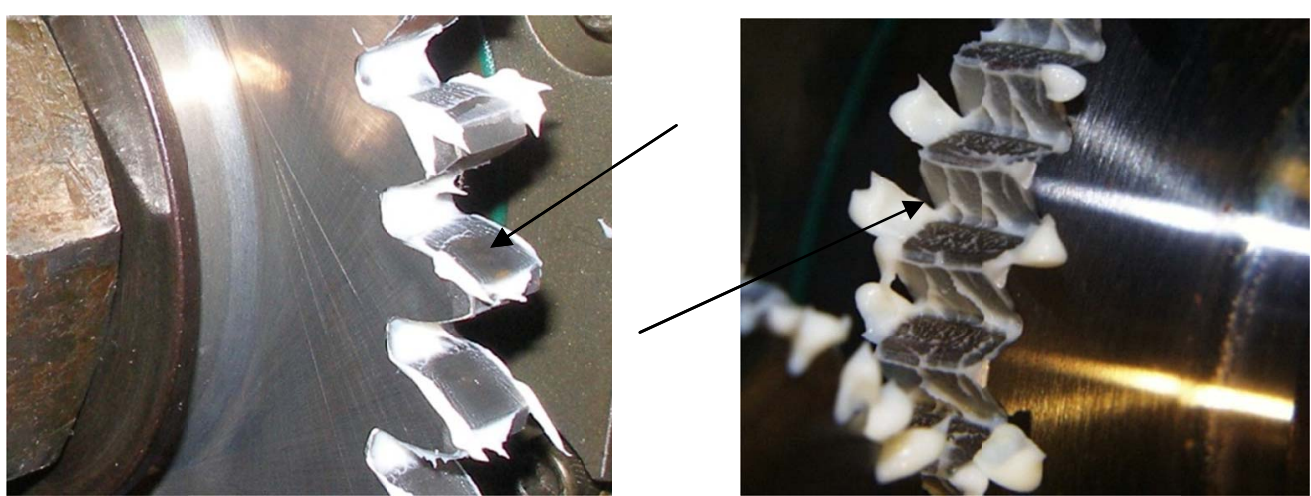

Figure 9.-Left: 20 degree pressure angle gear (3.18 module (8 Pitch)). Right: High-pressure angle gear 1.59 module (16 Pitch).

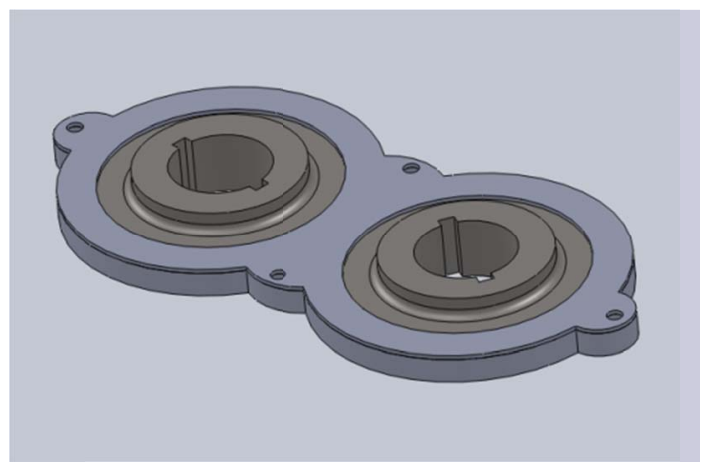

Figure 10.-Grease retention shroud CAD model.

In Figure 9(a) photograph of the trapped grease on the tooth profile of the 3.18 module ( 8 diametral pitch) and high-pressure angle gear can be seen. Both photographs in Figure 9 show the gears right after grease application. The static roll through mesh with the grease just applied demonstrates the need for some type of gear shrouding, as the grease is pushed to the root area and axially off the gear toothmeshing surface.

As a result of losing the grease, the gears experiencing accelerated wear. Metal-to-metal contact between the two mating gears left debris, discoloration, and rusting wear particles in the grease. As soon as the gears started rotating the grease would be lost to the outer walls of the housing, thus not serving the lubrication purpose.

Shrouding was needed to catch the grease for redistribution into the mesh. The shrouds were designed with a fairly tight clearance to the gears in axial and circumferential directions. The radial clearance to the tooth tips was $0.51 \mathrm{~mm}(0.020 \mathrm{in}$.), and axial clearance was approximately $0.20 \mathrm{~mm}$ (0.008 in.) on each side. The gears performed quite differently with the use of the grease retention shrouds. Each gearing configuration lost less mass due to wear than the previous non-shrouded gears.

A detailed model of the shrouds for each gear mesh was developed using a commercially available computer-aided design software (Ref. 11) and then produced using stereolithography (Fig. 10). As shown in Table 3, the high-pressure angle gears had zero mass loss for 500,000 cycles with the shrouds. The other two gear designs 3.18 and 2.12 module ( 8 and 12 pitch) gears had reduced mass loss. The shroud's ability to hold the grease, that is, flung off the gears and redistribute it to the gear system, proved that this concept will reduce gear wear. In Figure 11(a) detailed explanation of the shrouds in action is shown. Future investigation should be directed toward optimizing shrouding configurations to promote grease re-application and retention to promote good lubricating conditions. 


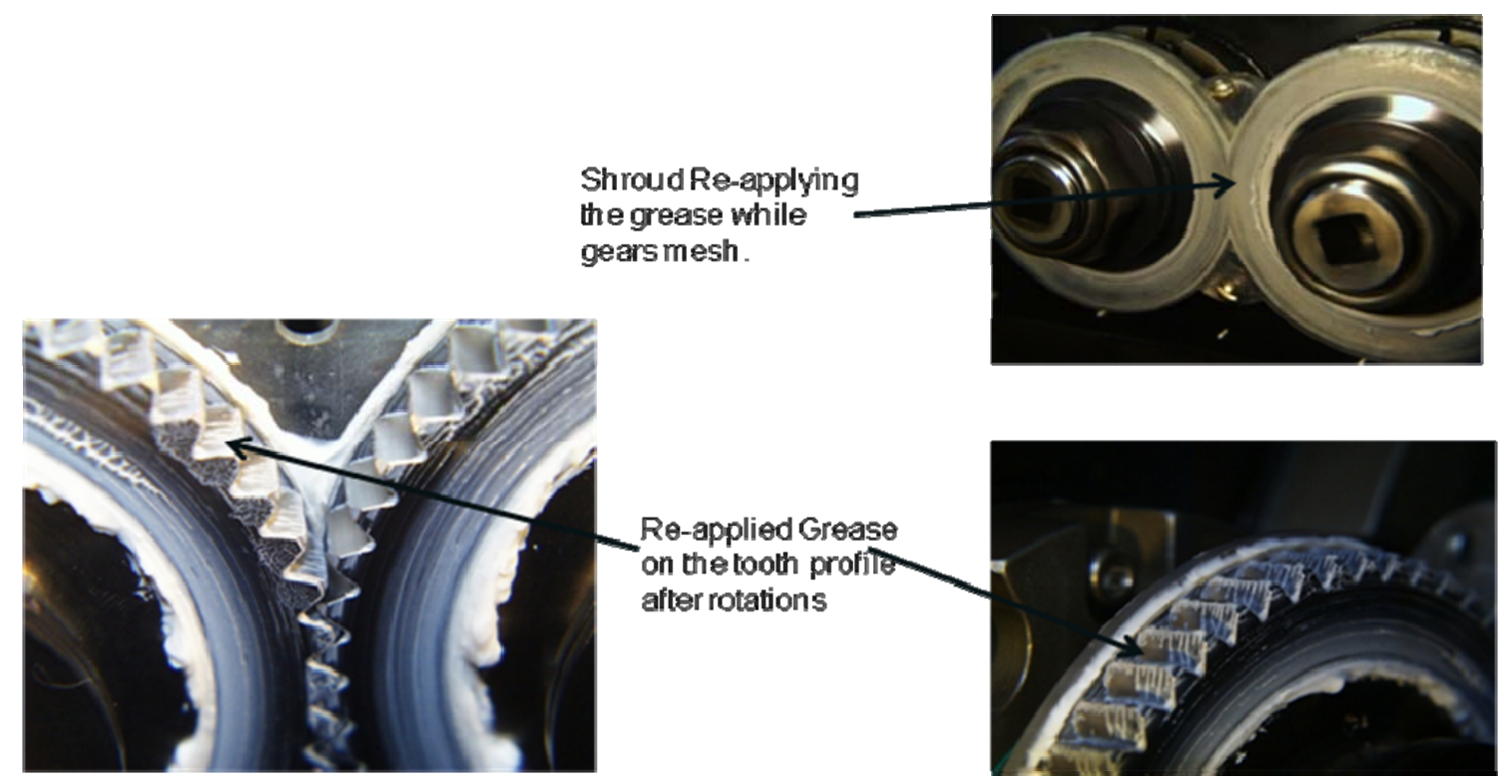

Figure 11.-Shrouds on the high-pressure angle gears during tests.

\section{Conclusions}

Based on the results obtained in this study, the following conclusions can be drawn:

1. High-pressure angle spur gears ( $35 \mathrm{deg}$ pressure angle) running at high-speed provide improved performance with similar bending and contact stress over more traditional gear pressure angles (20 deg). This was verified via analytical computer codes for efficiency, bending and contact stress analysis, as well as through experimental testing.

2. A general trend found from the experimental testing at identical conditions in the aerospace, jetlubricated configuration was that the higher the pressure angle, the lower the temperature increase of the lubricant across the gearbox. This is an indication of the improved efficiency.

3. The space grease-lubricated tests conducted at $150 \mathrm{rpm}$ and high load requires shrouding of the gear mesh to produce lower wear rates.

4. The high-pressure angle gears appeared to be better suited to the low-speed, high load, greaselubricated conditions compared to the 3.18 and 2.12 module ( 8 and 12 pitch) gears with perfluoroether-based space grease.

\section{References}

1. Krantz, T., Oswald, F., and Handschuh, R., 2007, "Wear of Spur Gears Having a Dithering Motion and Lubricated With a Perfluorinated Polyether Grease," NASA/TM-2007-215008; ARL-TR-4124, December 2007.

2. Krantz, T., and Handschuh, R., 2005, "A Study of Spur Gears Lubricated With GreaseObservations From Seven Experiments," NASA/TM-2005-213957, ARL-TR-3159, September 2005.

3. Drago, R., Fundamentals of Gear Design (Butterworth, Stoneham, MA, 1988).

4. Dudley, D., Handbook of Practical Gear Design (McGraw-Hill, New York, NY, 1984).

5. Townsend, D., 1992, Dudley's Gear Handbook, 2nd ed., McGraw-Hill, New York, NY.

6. Coy, J., Townsend, D., and Zaretsky, E., 1985, "Gearing," Report No. NASA RP-1152. 
7. Hohn, B.-R., Michaelis, K., and Wimmer. A., 2006, "Gearboxes With Minimized Power Loss," International Conference on Gears, September 2006, Munich Germany.

8. Schlecht, B., Martens, S., and Romhild, I., 2006, "Approaches to Oil-Free Gears," International Conference on Gears, September 2006, Munich Germany.

9. Anderson, N., and Lowenthal, S., 1986, "Efficiency of Nonstandard and High Contact Ratio Involute Spur Gears," ASME Journal of Mechanisms, Transmissions, and Automation in Design, 108, pp. 119-126.

10. ISO 6336 Gear Rating Program, Version 1.0, American Gear Manufacturers Association, 1997.

11. SolidWorks, CAD Venture Inc., Mentor, Ohio. 


\begin{tabular}{|c|c|c|c|c|c|}
\hline \multicolumn{5}{|c|}{ REPORT DOCUMENTATION PAGE } & $\begin{array}{l}\text { Form Approved } \\
\text { OMB No. 0704-0188 }\end{array}$ \\
\hline \multicolumn{6}{|c|}{ 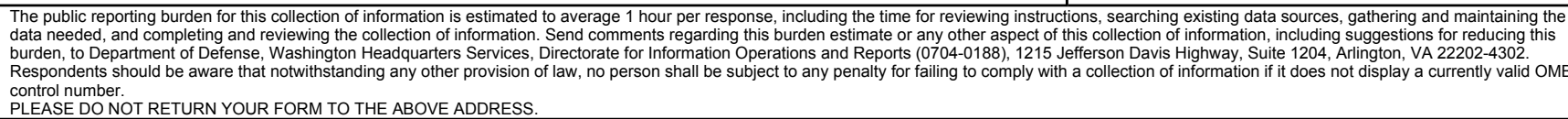 } \\
\hline \multicolumn{2}{|c|}{$\begin{array}{l}\text { 1. REPORT DATE (DD-MM-YYYY) } \\
01-06-2012\end{array}$} & \multicolumn{3}{|c|}{$\begin{array}{l}\text { 2. REPORT TYPE } \\
\text { Technical Memorandum }\end{array}$} & 3. DATES COVERED (From - To) \\
\hline \multirow{3}{*}{\multicolumn{5}{|c|}{$\begin{array}{l}\text { 4. TITLE AND SUBTITLE } \\
\text { High-Pressure Angle Gears: Comparison to Typical Gear Designs }\end{array}$}} & 5a. CONTRACT NUMBER \\
\hline & & & & & 5b. GRANT NUMBER \\
\hline & & & & & 5c. PROGRAM ELEMENT NUMBER \\
\hline \multirow{3}{*}{\multicolumn{5}{|c|}{$\begin{array}{l}\text { 6. AUTHOR(S) } \\
\text { Handschuh, Robert, F.; Zakrajsek, Andrew, J. }\end{array}$}} & 5d. PROJECT NUMBER \\
\hline & & & & & 5e. TASK NUMBER \\
\hline & & & & & $\begin{array}{l}\text { 5f. WORK UNIT NUMBER } \\
\text { WBS 877868.02.07.03.01.01.01 }\end{array}$ \\
\hline \multicolumn{5}{|c|}{$\begin{array}{l}\text { 7. PERFORMING ORGANIZATION NAME(S) AND ADDRESS(ES) } \\
\text { National Aeronautics and Space Administration } \\
\text { John H. Glenn Research Center at Lewis Field } \\
\text { Cleveland, Ohio 44135-3191 }\end{array}$} & $\begin{array}{l}\text { 8. PERFORMING ORGANIZATION } \\
\text { REPORT NUMBER } \\
\text { E-17238-2 }\end{array}$ \\
\hline \multirow{2}{*}{\multicolumn{5}{|c|}{$\begin{array}{l}\text { 9. SPONSORING/MONITORING AGENCY NAME(S) AND ADDRESS(ES) } \\
\text { National Aeronautics and Space Administration } \\
\text { Washington, DC 20546-0001 }\end{array}$}} & $\begin{array}{l}\text { 10. SPONSORING/MONITOR'S } \\
\text { ACRONYM(S) } \\
\text { NASA }\end{array}$ \\
\hline & & & & & $\begin{array}{l}\text { 11. SPONSORING/MONITORING } \\
\text { REPORT NUMBER } \\
\text { NASA/TM-2010-216251-REV1 }\end{array}$ \\
\hline \multicolumn{6}{|c|}{$\begin{array}{l}\text { 12. DISTRIBUTION/AVAILABILITY STATEMENT } \\
\text { Unclassified-Unlimited } \\
\text { Subject Category: } 37 \\
\text { Available electronically at http://www.sti.nasa.gov } \\
\text { This publication is available from the NASA Center for AeroSpace Information, 443-757-5802 }\end{array}$} \\
\hline \multicolumn{6}{|c|}{ 13. SUPPLEMENTARY NOTES } \\
\hline \multirow{2}{*}{\multicolumn{6}{|c|}{$\begin{array}{l}\text { 14. ABSTRACT } \\
\text { A preliminary study has been completed to determine the feasibility of using high-pressure angle gears in aeronautic and space applications. } \\
\text { Tests were conducted in the NASA GRC Spur Gear Test Facility at speeds up to } 10,000 \mathrm{rpm} \text { and } 73 \mathrm{~N} * \mathrm{~m} \text { ( } 648 \text { in.-lb) for } 3.18,2.12 \text {, and } \\
1.59 \text { module gears }(8,12 \text {, and } 16 \text { diametral pitch gears), all designed to operate in the same test facility. The } 3.18 \text { module }(8 \text {-diametral } \\
\text { pitch), } 28 \text { tooth, } 20 \text { degree pressure angle gears are the NASA GRC baseline test specimen. Also, } 2.12 \text { module (12-diametral pitch), } 42 \\
\text { tooth, } 25 \text { degree pressure angle gears were tested. Finally, } 1.59 \text { module (16-diametral pitch), } 56 \text { tooth, } 35 \text { degree pressure angle gears were } \\
\text { tested. The high-pressure angle gears were the most efficient when operated in the high-speed aerospace mode (10,000 rpm, lubricated with } \\
\text { a synthetic turbine engine oil) and produced the lowest wear rates when tested with a perfluoroether-based grease. The grease tests were } \\
\text { conducted at } 150 \mathrm{rpm} \text { and } 71 \mathrm{~N}^{*} \mathrm{~m}(630 \text { in.-lb). } \\
\text { 15. SUBJECT TERMS } \\
\text { Gears; Transmissions }\end{array}$}} \\
\hline & & & & & \\
\hline \multicolumn{3}{|c|}{ 16. SECURITY CLASSIFICATION OF: } & $\begin{array}{l}\text { 17. LIMITATION OF } \\
\text { ABSTRACT }\end{array}$ & $\begin{array}{l}\text { 18. NUMBER } \\
\text { OF }\end{array}$ & $\begin{array}{l}\text { 19a. NAME OF RESPONSIBLE PERSON } \\
\text { STI Help Desk (email:help@sti.nasa.gov) }\end{array}$ \\
\hline $\begin{array}{l}\text { a. REPORT } \\
\text { U }\end{array}$ & $\begin{array}{l}\text { b. ABSTRACT } \\
\text { U }\end{array}$ & $\begin{array}{l}\text { c. THIS } \\
\text { PAGE } \\
\text { U }\end{array}$ & UU & $\begin{array}{c}\text { PAGES } \\
15\end{array}$ & $\begin{array}{l}\text { 19b. TELEPHONE NUMBER (include area code) } \\
443-757-5802\end{array}$ \\
\hline
\end{tabular}


